\title{
Sperm-binding to the perivitelline membrane of chicken egg yolk as a functional test for sperm evaluation in dogs
}

\section{Teste de ligação espermática à membrana perivitelínica da gema de ovo de galinha como avaliação funcional do sêmen de cães}

\author{
Maíra Morales BRITO ${ }^{1}$; João Diego Agostini LOSANO룰 Daniel de Souza Ramos ANGRIMANI'; \\ Cristina de Fátima LUCIO $^{1}$; Andressa DALMAZZO ${ }^{1}$; Marcílio NICHI ${ }^{1}$; Camila Infantosi VANNUCCHI ${ }^{1}$
}

${ }^{1}$ Universidade de São Paulo, Faculdade de Medicina Veterinária e Zootecnia, Departamento de Reprodução Animal, São Paulo - SP, Brazil

\begin{abstract}
During fertilization, spermatozoa interact with the zona pellucida (ZP) through the binding between the acrosome and proteins 2 and 3 (ZP2 and ZP3). The perivitelline membrane of chicken egg yolk is homologous to the mammalian ZP3, which allows the binding of sperm of several species. The aim of this study was to standardize and evaluate the efficiency of sperm-binding to the perivitelline membrane of chicken eggs as a functional method for canine semen evaluation. For this purpose, nine post-thaw sperm samples were used, which were divided into two aliquots: the first was kept in water bath at $37^{\circ} \mathrm{C}$ (live sample) and the second was submitted to cold shock to induce cellular damage (dead sample). The two aliquots were mixed on five proportions, corresponding to $0 \%, 25 \%, 50 \%, 75 \%$, and $100 \%$ of viable cells, and the binding test was performed by analyzing the number of spermatozoa bonded to the perivitelline membrane by means of computerized assessment of sperm motility (CASA) or conventional microscopy. Additionally, samples were submitted to sperm motility analysis, evaluation of plasmatic and acrosomal membrane integrity, and sperm mitochondrial activity. The sperm-binding test to the perivitelline membrane of chicken egg yolk was considered a feasible sperm analysis test for both fertilizing capacity and overall sperm attributes evaluation, mainly when the analysis is performed by a conventional microscope, which expands its practicality to the majority of canine reproduction laboratories.
\end{abstract}

Keywords: Sperm cryopreservation. Egg yolk. Sperm analysis. Perivitelline membrane. Canine.

\section{Resumo}

Durante a fecundação, os espermatozoides interagem com a zona pelúcida (ZP) por meio da ligação entre o acrossomo e as proteínas 2 e 3 (ZP2 e ZP3). A membrana perivitelínica da gema de ovo de galinhas é homóloga à ZP3 de mamíferos, possibilitando a ligação espermática de diversas espécies. Este trabalho padronizou e avaliou a eficiência do teste de ligação espermática à membrana perivitelínica da gema de ovo de galinhas como avaliação funcional do sêmen de cães. Para tal, foram utilizadas nove amostras seminais previamente criopreservadas. Cada amostra foi dividida em duas alíquotas: a primeira foi mantida em banho-maria à $37^{\circ} \mathrm{C}$ (vivos) e a segunda submetida a choque térmico com o intuito de induzir dano celular (mortos). As duas alíquotas foram misturadas, correspondendo a 0, 25, 50, 75 e 100\% de células viáveis. As amostras foram avaliadas quanto ao número de espermatozoides ligados à membrana perivitelínica por meio da análise computadorizada da motilidade (CASA) ou microscopia convencional. Ademais, as amostras foram avaliadas quanto à motilidade espermática, integridade das membranas acrossomal e plasmática e atividade mitocondrial espermática. $\mathrm{O}$ teste de ligação espermática à membrana perivitelínica de ovos de galinha foi considerado um teste de análise seminal exequível tanto para avaliar a capacidade fecundante dos espermatozoides como atributos seminais gerais, especialmente quando realizado em microscopia convencional, expandindo sua praticidade para a maioria dos laboratórios de análise de sêmen canino.

Palavras-chave: Criopreservação seminal. Gema de ovo. Análise espermática. Membrana perivitelínica. Caninos. 
Correspondence to:

Camila Infantosi Vannucchi

Universidade de São Paulo, Facudade de Medicina Veterinária

e Zootecnia, Departamento de Reprodução Animal

Rua Prof. Orlando Marques de Paiva, 87 - Cidade

Universitária

CEP 05508-270, São Paulo, SP, Brazil

e-mail: cacavann@usp.br

Received: 21/02/2017

Approved: 11/10/2017

\section{Introduction}

Currently several studies have aimed at improving the knowledge of the reproductive physiology of dogs, contributing directly to the development of new biotechnologies (FARSTAD, 2000; THOMASSEN; FARSTAD, 2009). Among these novel reproductive biotechniques for the canine species, a major interest is given to artificial insemination and sperm cryopreservation (LASLEY et al., 1994). In fact, the improvement of reproductive biotechniques is essential for the preservation of genetic material from selected animals. However, the sperm quality for reproductive manipulations has to be guaranteed (LOSANO et al., 2015). Thus, semen needs to be accurately evaluated (AITKEN, 2006).

In addition to conventional tests for seminal assessment (i.e. sperm motility, vigor, and morphology), functional tests can also be conducted, allowing the estimation of the sperm's fertilizing capacity. Hypo-osmotic test, induction of acrosome reaction and zona pellucida penetration, hyperactivation tests, and penetration of zona-free hamster oocytes are some important tests described (AITKEN, 2006; FRANKEN; OEHNINGER, 2012). However, such tests have reduced practical applicability for conventional sperm analysis laboratories, since they are expensive, laborious, and difficult to implement, and require specific equipment and materials. Thus, the sperm-binding to the perivitelline membrane of chicken eggs arises as an alternative test for sperm functional evaluation, as it allows an indirect and accurate analysis of the ejaculate fertilizing capacity (LOSANO et al., 2015). In other words, it can be carried out more frequently for seminal evaluation, being more accessible, more practical, and cheaper for dog breeders.

During fertilization spermatozoa interact with the oocyte through the binding between the acrosome and proteins 2 and 3 (ZP2 and ZP3) present in the zona pellucida (YANAGIMACHI, 1994). The perivitelline membrane of chicken eggs has a homologous mammalian ZP3, which allows the binding of sperm of several animal species (WACLAWEK et al., 1998; BAUSEK et al., 2000). However, to our knowledge no studies regarding the standardization and evaluation of the efficiency of sperm-binding test to the perivitelline membrane of chicken eggs have been undertaken for canine sperm, mainly for post-thaw sperm samples. Conversely, tests have been performed for domestic birds, bulls, stallions, ram, boars, mice, and humans (ROBERTSON et al., 1997; BARBATO et al., 1998; WACLAWEK et al., 1998; AMANN et al., 1999; CORCINI et al., 2012; LOSANO et al., 2015). Thus, the aim of this study was to standardize and evaluate the efficiency of the sperm-binding test to the perivitelline membrane of chicken eggs as a functional method for canine semen evaluation.

\section{Material and Methods}

The present study was approved by the Bioethics Committee (CEUA) of the Faculty of Veterinary Medicine and Animal Science (University of São Paulo) (protocol number 3032/2013).

The standardization of the sperm-binding test to the perivitelline membrane of chicken eggs was performed on canine post-thaw sperm samples, according to the technique described by Criscuolo et al. (2010) for human semen, using a total of 9 previously cryopreserved samples.

\section{Egg perivitelline membrane (EPM) processing}

Fresh and unfertilized hen eggs were broken and the albumen was removed. With the use of a scalpel blade, a semi-circular incision was made in the perivitelline membrane and the excess of yolk was carefully removed manually. Then, the membrane was transferred to a Petri dish containing PBS (phosphate buffered saline) in order to remove traces of yolk by softly shaking the membrane. The washing procedure was performed four times until the membrane and PBS were translucent. Subsequently, using a scalpel blade the membrane was cut into squares of approximately $0.5 \mathrm{~cm}$ on each side and then transferred to a plate containing wells for sperm incubation.

\section{Preparation of seminal samples}

Previously cryopreserved semen samples from nine dogs were thawed in water bath at $37^{\circ} \mathrm{C}$ for 30 seconds and transferred to a $2-\mathrm{mL}$ plastic microtube for evaluation. Then, each seminal sample was divided into two aliquots: the first one was kept in water bath at $37^{\circ} \mathrm{C}$ (live sample) 
and the second was submitted to cold shock in order to induce cellular damage (dead sample). To induce cold shock, sperm was four times immersed into liquid nitrogen and later in water bath at $37^{\circ} \mathrm{C}$. Samples were analyzed for sperm motility and vigor in order to assure total cell death. The two aliquots (live and dead samples) were mixed in proportions of 0:100, 25:75, 50:50, 75:25, and 100:0 respectively, corresponding approximately to $0 \%, 25 \%$, $50 \%, 75 \%$, and $100 \%$ of viable cells. All five proportions were submitted to seminal analysis.

\section{Seminal analysis}

For the computerized assessment of sperm motility through the Hamilton Thorne equipment (CASA; HTM-IVOS-Ultimate 12.3; Hamilton Thorne Biosciences, Beverly, MA, USA), $5 \mu$ l of semen were placed in a prewarmed glass slide with coverslip and eight fields of view were randomly selected for the analysis of the following variables: velocity average pathway (VAP; $\mu \mathrm{m} / \mathrm{s}$ ), curvilinear velocity (VCL; $\mu \mathrm{m} / \mathrm{s}$ ), velocity straight line (VSL; $\mu \mathrm{m} / \mathrm{s}$ ), amplitude of lateral head displacement $(\mathrm{ALH} ; \mu \mathrm{M})$, beat cross-frequency (BCF; Hz), straightness (STR; \%), linearity (LIN; \%), total motility (MOT; \%), and progressive motility (PROG; \%). Sperm was additionally divided into 4 groups based on spermatozoa speed: fast (RAP - \%), medium (MED - \%), slow (SLOW - \%) and static sperm (STATIC - \%) (VERSTEGEN et al., 2002).

In order to evaluate sperm plasma membrane integrity eosin-nigrosine stain was utilized. An aliquot of semen $(5 \mu \mathrm{L})$ was mixed with the stain $(5 \mu \mathrm{L})$ at $37^{\circ} \mathrm{C}$ and samples were smeared on glass slides. After drying, 200 cells were counted under light microscopy (Nikon, Eclipse E200, Japan) at 1000x magnification. Damaged sperm (membrane lesion) was considered as pink colored cells, while intact sperm (membrane integrity) presented no stain (LAGERGREN, 1953).

The determination of acrosome membrane integrity was performed by the modified Fast Green/Rose Bengal stain (POPE et al., 1991). For the analysis, an aliquot of each sample $(5 \mu \mathrm{L})$ was placed on a microscope slide and $5 \mu \mathrm{L}$ of stain were added. Smears were evaluated under light microscopy (Nikon, Eclipse E200, Japan) at 1000x magnification by counting 200 cells and classified as intact acrosome (purple to dark purple stain at the acrosomal region, slightly darker than the post-acrosomal region) and damaged acrosome (pink stain at the acrosomal region, slightly lighter than the post-acrosomal region).
Sperm mitochondrial activity was determined by the citochemical technique of 3.3 '-diaminobenzidine (DAB) (HRUDKA, 1987). To carry out this test, semen samples were incubated with DAB stain at 1:1 proportion at $37^{\circ} \mathrm{C}$ for one hour. After this period, samples were smeared on glass slides with subsequent fixation in formalin $10 \%$ for ten minutes. The slides were then examined under a phase-contrast microscope (1000x) by counting 200 cells which were classified into four classes: in Class I (high mitochondrial activity) the midpiece was completely stained; in class II (medium mitochondrial activity) more than $50 \%$ of the midpiece was stained; in class III (low mitochondrial activity) less than $50 \%$ of the midpiece was stained, while in class IV (absence of mitochondrial activity) no staining was observed in the midpiece.

\section{Sperm-binding test to the perivitelline membrane of chicken egg yolk and its interpretation}

All sperm proportions $(0 \%, 25 \%, 50 \%, 75 \%$, and $100 \%$ of live cells) were incubated with the perivitelline membrane of chicken egg yolk at a concentration of 50 x $10^{6}$ sperm diluted in $250 \mu \mathrm{L}$ of Canine Capacitating Medium [ $83.49 \mathrm{mM} \mathrm{NaCl}, 4.78 \mathrm{mM} \mathrm{KCl}, 1.71 \mathrm{mM} \mathrm{CaCl} 2$ 2H2O, 1.19 mM KH2PO4, $37.61 \mathrm{mM} \mathrm{NaHCO} 3,0.25 \mathrm{mM}$ Na pyruvate, $21.55 \mathrm{mM}$ Syrup Na lactate $60 \%, 2.78 \mathrm{mM}$ glucose, $56.4 \mu \mathrm{m}$ Phenol Red, 0.4\% (w/v) BSA (PEÑA et al, 2012)] at $37^{\circ} \mathrm{C}$ for 1 hour.

After incubation, membranes were washed in $10 \mathrm{~mL}$ of PBS for the removal of non-bonded sperm. Then, the membranes were extended on a microscopy slide and covered with $10 \mu \mathrm{L}$ of the sperm DNA stain Ident ${ }^{\circledR}$ fluorescent probe (Hamilton Thorne Biosciences, Beverly, MA, USA), which remained at room temperature for 7 minutes (LOSANO et al., 2015). The membranes were covered with a coverslip and then submitted to computerized assessment of sperm motility.

Sperm bonded to the membrane were counted among three to five fields, for the subsequent calculation of the number of sperm bonded per $\mathrm{mm}^{2}$ of the membrane. The same procedure was performed in a conventional light microscopy (Nikon, Eclipse E200, Japan), by counting only the sperm bonded (in three fields) at 400x magnification.

The area of the entire membrane was estimated by the use of a Neubauer chamber, making it possible to calculate the number of sperm bonded per $\mathrm{mm}^{2}$ of membrane. 


\section{Statistical analysis}

Data were analyzed using the SAS System for Windows program. Data were tested by the Guided Data Analysis application considering the residual normality (normal distribution) and the homogeneity of variances. If not obeying these premises data were transformed according to the suggestions of the software (logarithm in base 10 - Log10X; Square root - RQ X; Square -X2, arcsine - $\arcsin (\mathrm{X})$; among others) and if normality was not obtained, then, the NPAR1WAY procedure for nonparametric variance analysis was used. For the parametric analysis we used the Least Significant Differences (LSD) test for comparisons between groups. Validation was accepted when linear regression coefficient of determination $\left(\mathrm{R}^{2}\right)$ between the number of sperm bonded to membrane and the proportion of live:dead sperm was higher than 0.9 .

The response variables were also submitted to the correlation tests of Pearson and Spearman for the parametric and nonparametric variables, respectively. Results were described as untransformed means \pm SE. The significance level used was $5 \%$.

\section{Results}

We observed an increase in the number of sperm bonded to the perivitelline membrane according to the proportion of live sperm by both the analyses of CASA and conventional microscopy. Concerning the CASA analysis, the percentage of $0 \%$ live sperm presented $1.41 \pm 0.43$ spermatozoa bonded to the membrane, while $25 \%$ had $11.74 \pm 5.65,50 \%$ had $27.29 \pm 5.1,75 \%$ had $59.22 \pm 16.51$, and $100 \%$ live sperm had $69.29 \pm 21.9$ spermatozoa bonded to the membrane (Figure 1). In the analysis conducted by the conventional light microscopy the percentage of $0 \%$ live sperm presented $0.73 \pm 0.4$ spermatozoa bonded to the membrane, while $25 \%$ had $2.12 \pm 0.5,50 \%$ had $14.73 \pm 3.31,75 \%$ had $25.51 \pm 3.69$, and $100 \%$ live cells had $52.89 \pm 10.54$ spermatozoa bonded to the membrane (Figure 2).

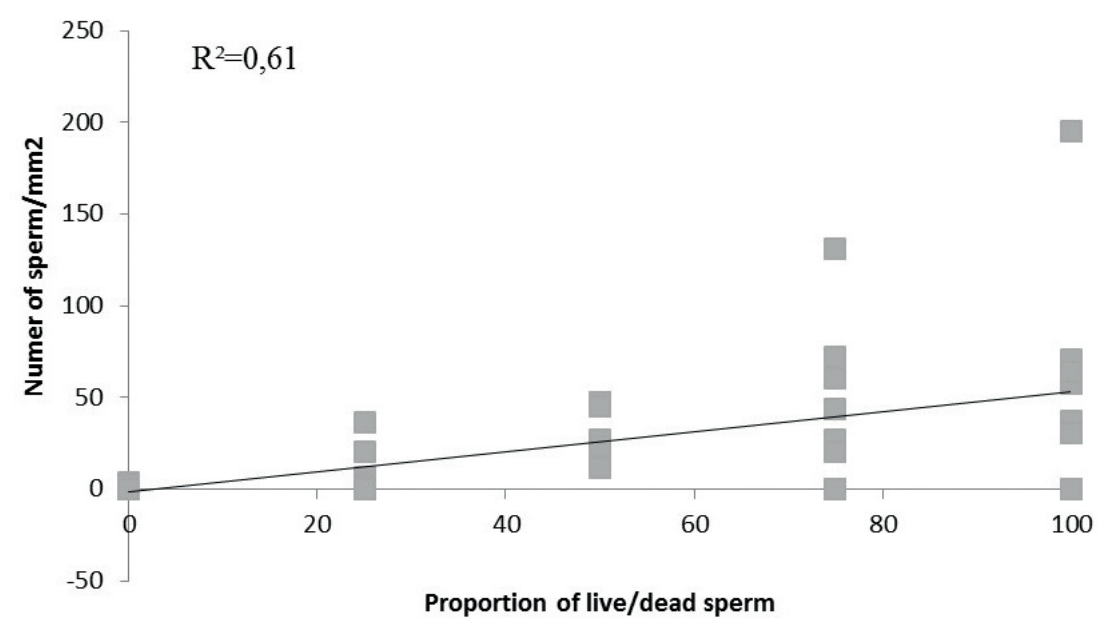

Figure 1 - Number of sperm bonded to the perivitelline membrane of chicken eggs (per $\mathrm{mm}^{2}$ ) evaluated by the ComputerAssisted Sperm Analysis (CASA) on different proportions of sperm viability (0\%, 25\%, 50\%, 75\%, and $100 \%)$

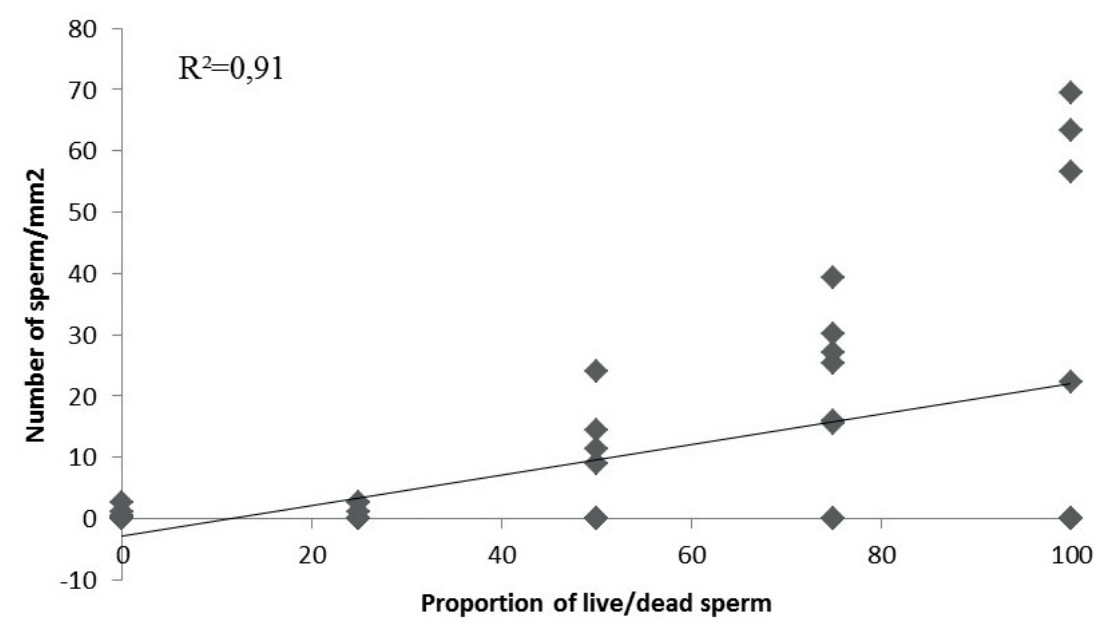

Figure 2 - Number of sperm bonded to the perivitelline membrane of chicken eggs (per $\mathrm{mm}^{2}$ ) evaluated by conventional microscopy on different proportions of sperm viability $(0 \%, 25 \%, 50 \%, 75 \%$, and $100 \%)$ 
The linear regression coefficient $\left(\mathrm{R}^{2}\right)$ for the number of spermatozoa bonded to the membrane evaluated by CASA did not achieve the limit for statistical validation $(0,61)$ (Figure 1). On the other hand, the $\mathrm{R}^{2}$ for the number of spermatozoa bonded to the membrane assessed by conventional optical microscopy was above 0.9 (Figure 2).

There was a significant difference for the assessment of post-thaw plasmatic and acrosomal membrane integrity. We observed an increase in the number of sperm cells with plasmatic and acrosomal membrane integrity, in accordance with the highest proportion of live sperm (Figure 3).

For the plasmatic membrane integrity, statistical difference was observed among different proportions, except between $50 \%$ and $75 \%$ of live cells, i.e. $0 \%$ of live sperm presented $0.56 \pm 0.44 \%, 25 \%$ had $11.44 \pm 2.95 \%$,
$50 \%$ had $20.11 \pm 2.71 \%, 75 \%$ had $26.78 \pm 2.99 \%$, and $100 \%$ of live sperm had $43.33 \pm 3.01 \%$ of plasma membrane integrity. Regarding the acrosome membrane integrity no statistical difference was observed between $50 \%$ and $25 \%$ or $75 \%$, while $75 \%$ did not differ from $100 \%$. We noticed that $0 \%$ of live cells presented $64.44 \pm 3.35 \%$, $25 \%$ had $74.61 \pm 2.77 \%, 50 \%$ had $80.39 \pm 1.81 \%, 75 \%$ had $85.83 \pm 1.75 \%$, and $100 \%$ of live sperm had $91.78 \pm 1.4 \%$ of acrosome membrane integrity.

Regarding the analysis of mitochondrial activity evaluated by the DAB technique, higher mitochondrial activity was noted as the proportion of live sperm increased (Figure 4), i.e., the percentage of sperm with high and medium mitochondrial activity was higher than the percentage of sperm with low or absent mitochondrial activity.

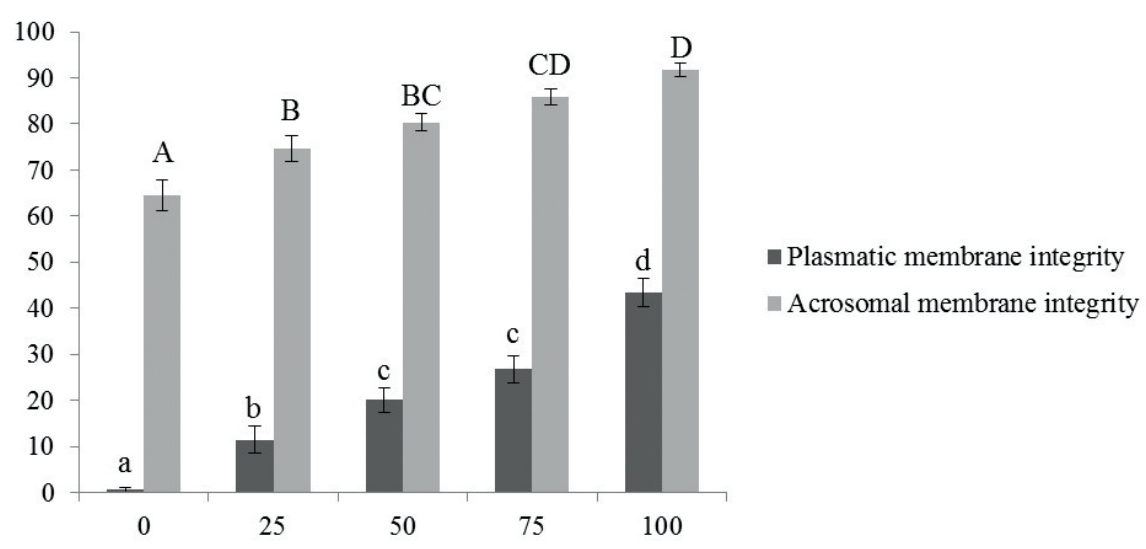

Figure 3 - Percentage of sperm with plasmatic and acrosome membrane integrity on different proportions of sperm viability $(0 \%, 25 \%, 50 \%, 75 \%$, and $100 \%) .{ }^{\mathrm{a}-\mathrm{d}}$ and ${ }^{\mathrm{A}-\mathrm{D}}$ indicate statistical difference between proportions $(\mathrm{P}<0.05)$

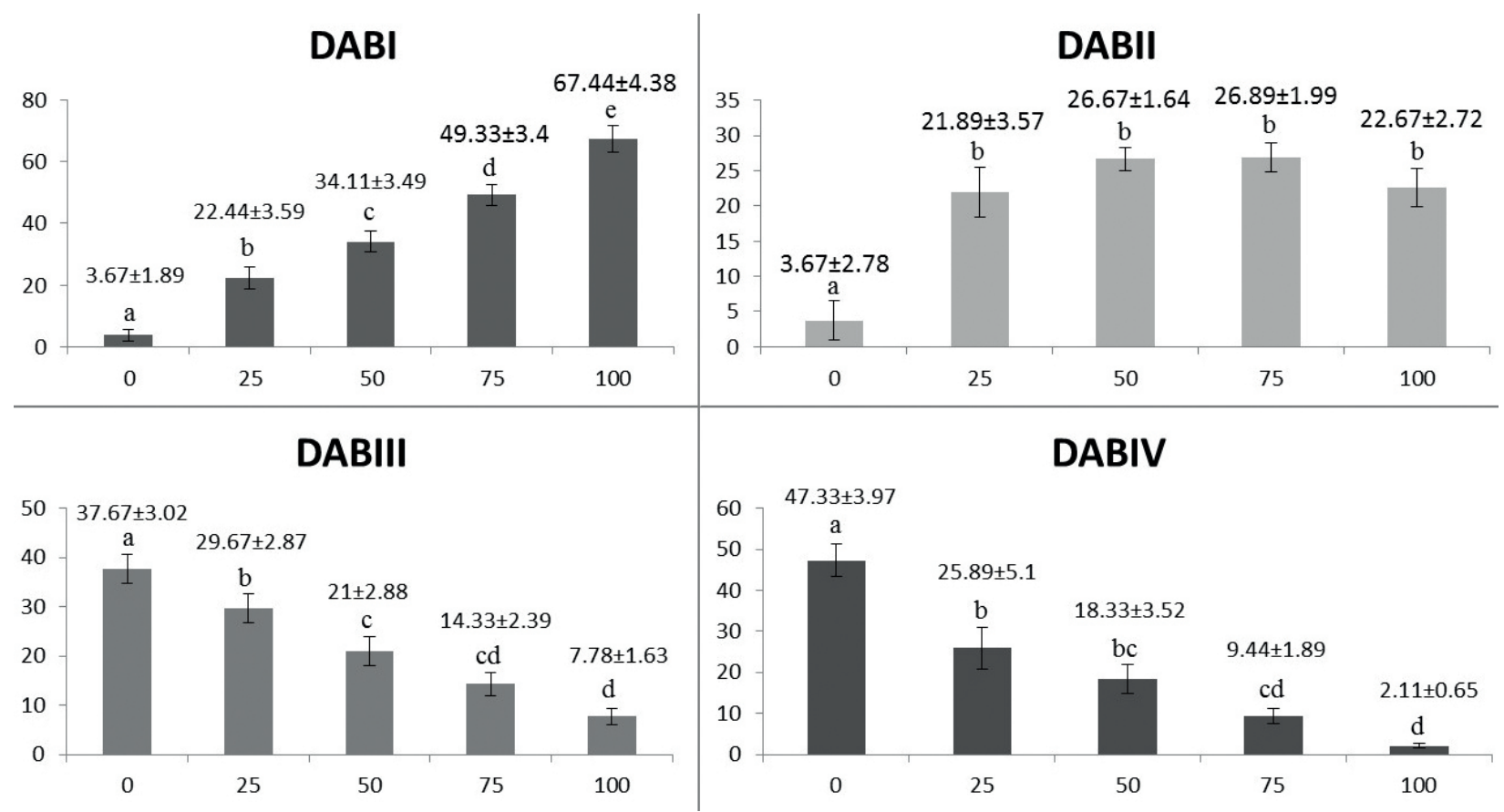

Figure 4 - Percentage of sperm with high (DAB I), medium (DAB II), low (DAB III), and absent (DAB IV) mitochondrial activity on different proportions of sperm viability $(0 \%, 25 \%, 50 \%, 75 \%$, and $100 \%)$. ${ }^{\text {a-e }}$ indicate statistical difference between proportions $(\mathrm{P}<0.05)$ 
Table 1 - Media and standard error of sperm variables of the Computer-Assisted Sperm Analysis (CASA) on different proportions of sperm viability $(0 \%, 25 \%, 50 \%, 75 \%$, and 100\%) - São Paulo -2017

\begin{tabular}{lccccc}
\hline & $\mathbf{0}$ & $\mathbf{2 5}$ & $\mathbf{5 0}$ & $\mathbf{7 5}$ & $\mathbf{1 0 0}$ \\
\hline Sperm velocity average pathway $(\mu \mathrm{m} / \mathrm{s})$ & $0 \pm 0^{\mathrm{a}}$ & $104.34 \pm 9.62^{\mathrm{b}}$ & $84.22 \pm 9.53^{\mathrm{b}}$ & $108.4 \pm 12.72^{\mathrm{b}}$ & $108.13 \pm 10.34^{\mathrm{b}}$ \\
Sperm velocity straight line $(\mu \mathrm{m} / \mathrm{s})$ & $0 \pm 0^{\mathrm{a}}$ & $81.28 \pm 7.93^{\mathrm{b}}$ & $70.7 \pm 9.15^{\mathrm{b}}$ & $89.7 \pm 9.98^{\mathrm{b}}$ & $89.91 \pm 7.36^{\mathrm{b}}$ \\
Sperm curvilinear velocity $(\mu \mathrm{m} / \mathrm{s})$ & $0 \pm 0^{\mathrm{a}}$ & $168.89 \pm 14.9^{\mathrm{b}}$ & $123.11 \pm 12.05^{\mathrm{c}}$ & $157.62 \pm 18.66^{\mathrm{bc}}$ & $156.9 \pm 17.03^{\mathrm{bc}}$ \\
Amplitude of lateral head displacement $(\mu \mathrm{m})$ & $0 \pm 0^{\mathrm{a}}$ & $5.62 \pm 0.6^{\mathrm{b}}$ & $3.44 \pm 0.49^{\mathrm{c}}$ & $3.91 \pm 0.42^{\mathrm{c}}$ & $4.11 \pm 0.33^{\mathrm{c}}$ \\
Sperm beat cross-frequency $(\mathrm{Hz})$ & $0 \pm 0^{\mathrm{a}}$ & $4.69 \pm 3.24^{\mathrm{a}}$ & $5.18 \pm 3.74^{\mathrm{a}}$ & $1.63 \pm 0.8^{\mathrm{a}}$ & $0.79 \pm 0.23^{\mathrm{a}}$ \\
Sperm straightness (\%) & $0 \pm 0^{\mathrm{a}}$ & $77.44 \pm 4.32^{\mathrm{b}}$ & $81.67 \pm 2^{\mathrm{b}}$ & $84 \pm 1.92^{\mathrm{b}}$ & $84.33 \pm 2.52^{\mathrm{b}}$ \\
Sperm linearity (\%) & $0 \pm 0^{\mathrm{a}}$ & $52.11 \pm 3.28^{\mathrm{b}}$ & $59.22 \pm 2.59^{\mathrm{bc}}$ & $60.11 \pm 2.95^{\mathrm{bc}}$ & $63 \pm 3.93^{\mathrm{c}}$ \\
Total sperm motility (\%) & $0 \pm 0^{\mathrm{a}}$ & $7.44 \pm 1.44^{\mathrm{b}}$ & $12 \pm 1.64^{\mathrm{b}}$ & $19.78 \pm 2.78^{\mathrm{c}}$ & $33.89 \pm 4.09^{\mathrm{d}}$ \\
Sperm progressive motility $(\%)$ & $1 \pm 1^{\mathrm{a}}$ & $3.44 \pm 0.97^{\mathrm{a}}$ & $5.56 \pm 1.79^{\mathrm{ab}}$ & $9.44 \pm 2.09^{\mathrm{b}}$ & $19.44 \pm 2.73^{\mathrm{c}}$ \\
Percentage of fast sperm (\%) & $0 \pm 0^{\mathrm{a}}$ & $4.89 \pm 1.27^{\mathrm{ab}}$ & $7 \pm 1.99^{\mathrm{b}}$ & $12.56 \pm 1.91^{\mathrm{c}}$ & $22.89 \pm 2.79^{\mathrm{d}}$ \\
Percentage of medium sperm $(\%)$ & $0 \pm 0^{\mathrm{a}}$ & $2.78 \pm 0.57^{\mathrm{ab}}$ & $5.11 \pm 1.27^{\mathrm{ab}}$ & $7.33 \pm 2.54^{\mathrm{bc}}$ & $11.33 \pm 3.44^{\mathrm{c}}$ \\
Percentage of slow sperm $(\%)$ & $9.67 \pm 6.23^{\mathrm{a}}$ & $11.33 \pm 3.27^{\mathrm{a}}$ & $19.22 \pm 5.08^{\mathrm{a}}$ & $15.89 \pm 3.71^{\mathrm{a}}$ & $13.78 \pm 5.27^{\mathrm{a}}$ \\
Percentage of static sperm (\%) & $90.33 \pm 6.23^{\mathrm{a}}$ & $81.11 \pm 4.47^{\mathrm{ab}}$ & $68.89 \pm 4.76^{\mathrm{bc}}$ & $64.11 \pm 5.79^{\mathrm{bc}}$ & $52.11 \pm 8.49^{\mathrm{c}}$ \\
\hline
\end{tabular}

a-e indicate statistical difference between proportions $(\mathrm{P}<0.05)$

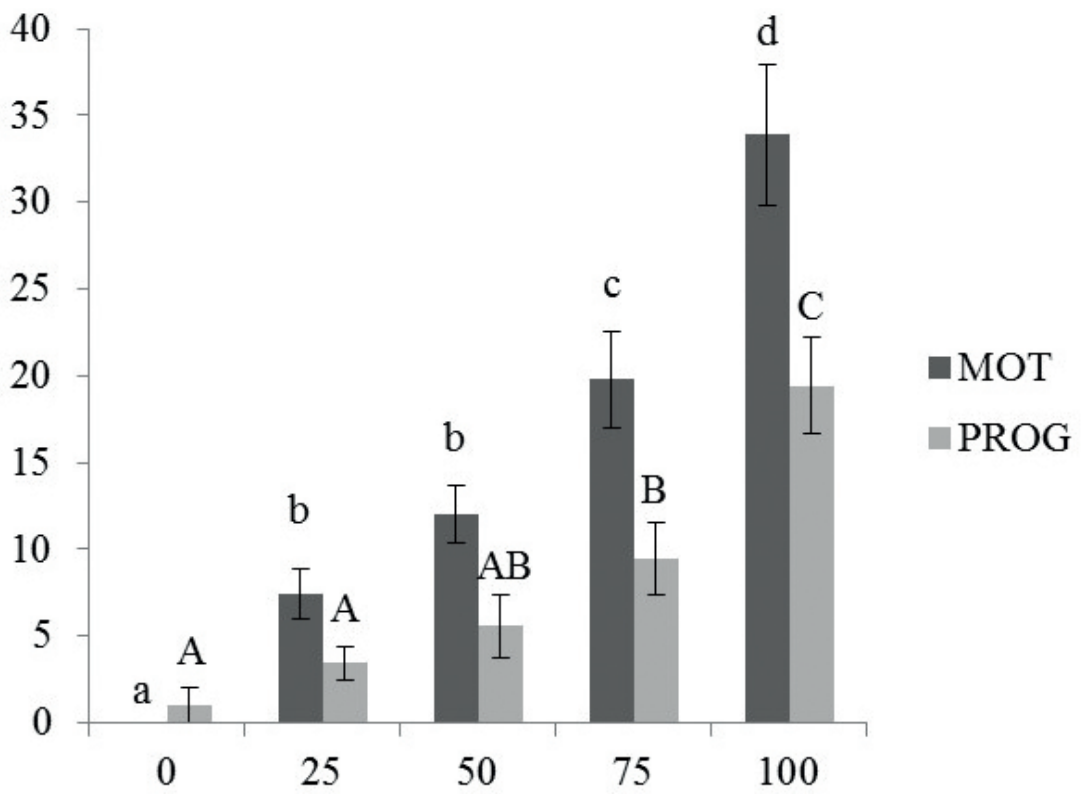

Figure 5 - Percentage of sperm motility and progressive motility on different proportions of sperm viability $(0 \%, 25 \%, 50 \%, 75 \%$, and $100 \%) .^{A-D} e^{a-d}$ indicate statistical difference between proportions $(\mathrm{P}<0.05)$

Table 2 - Spearman correlation coefficients for the experimental variables of sperm-binding to the perivitelline membrane (Microscopy and CASA), plasmatic and acrosome membrane integrity, mitochondrial activity (DAB I, DAB II, DAB III and DAB IV), sperm motility, and progressive motility - São Paulo - 2017

\begin{tabular}{|c|c|c|c|c|c|c|c|c|}
\hline & $\begin{array}{l}\text { Acrosome } \\
\text { membrane } \\
\text { integrity }\end{array}$ & $\begin{array}{l}\text { Plasmatic } \\
\text { membrane } \\
\text { integrity }\end{array}$ & DAB I & DAB II & DAB III & DAB IV & $\begin{array}{l}\text { Sperm } \\
\text { Motility }\end{array}$ & $\begin{array}{c}\text { Progressive } \\
\text { motility }\end{array}$ \\
\hline $\begin{array}{l}\text { Sperm } \\
\text { binding }\end{array}$ & 0.67 & 0.77 & 0.76 & 0.52 & -0.56 & -0.76 & 0.72 & 0.72 \\
\hline (CASA) & $<.0001$ & $<.0001$ & $<.0001$ & 0.0012 & 0.0003 & $<.0001$ & $<.0001$ & $<.0001$ \\
\hline $\begin{array}{l}\text { Sperm } \\
\text { binding }\end{array}$ & 0.75 & 0.85 & 0.85 & 0.55 & -0.67 & -0.86 & 0.91 & 0.68 \\
\hline (microscopy) & $<.0001$ & $<.0001$ & $<.0001$ & 0.0067 & 0.0005 & $<.0001$ & $<.0001$ & 0.0004 \\
\hline
\end{tabular}


The proportion of $0 \%$ of live sperm showed the lowest results of sperm motility parameters (linearity, total motility, progressive motility and fast velocity) in comparison to the remaining proportions, with a gradual increase in progressive sperm motility as the proportion of live sperm raised (Table 1 and Figure 5).

Considering the correlation analysis, a positive correlation between the number of sperm bonded to the perivitelline membrane and the percentage of spermatozoa with plasma and acrosome membrane integrity, high mitochondrial activity, motility, and progressive motility might be observed (Table 2). Moreover, there was a negative correlation between the number of sperm bonded to the perivitelline membrane and the absence of sperm mitochondrial activity (Table 2).

\section{Discussion}

Functional tests that analyze the sperm binding to the zona pellucida of canine oocytes are difficult to apply mainly because of the impossibility to obtain viable canine oocytes (HERMANSSON et al., 2006). In this context the sperm-binding test to the perivitelline membrane of chicken egg yolk can be a feasible possibility for dog sperm analysis. In fact, in this experiment the test was considered accessible, practical, and inexpensive for seminal analysis, being a promising evaluation technique for laboratories of canine reproduction.

Although all sperm variables analyzed had significant correlation with the number of sperm bonded to the perivitelline membrane, the low linear regression coefficient $\left(\mathrm{R}^{2}\right)$ resulting from the CASA evaluation shows that in the canine species the test is more reliable when performed by a conventional microscope. The inaccuracy of the CASA analysis can be due to the inability of the equipment to differentiate the spermatozoa bonded to the membrane from artifacts of the sperm slide, as the canine sperm has a small length (approximately $7 \mu \mathrm{m}$; DAHLBOM et al., 1997), which gendered the confused interpretation. The analysis of the sperm bonded to the perivitelline membrane using the CASA analysis system has been previously validated for the bovine species by Losano et al. (2015).
However, the bovine sperm has an average size of $9.1 \mu \mathrm{m}$ (BOERSMA et al., 2001), 1.3 times bigger than the canine sperm. Therefore, it was concluded that the use of the CASA system was unsuitable for the analysis of canine sperm bonded to the perivitelline membrane. Moreover, conventional microscopy has the advantage of being less expensive when compared to CASA, making the test feasible for almost all laboratories of canine reproduction.

In the present experiment we verified that the reduction in the proportion of plasma and acrosome membrane integrity accompanied the decrease in sperm motility and progressive motility, which in turns reduced the number of spermatozoa bonded to the perivitelline membrane. In fact, it is important that the acrosome membrane remains intact for the successful binding to the oocyte, in order to avoid the loss of acrosomal enzymes (LUCIO et al., 2016). Therefore, the binding test to the perivitelline membrane not only indicates sperm fertilizing capacity, but also indirectly assures acrosome membrane integrity. Moreover, the sperm binding test presented high correlation with important semen quality parameters such as sperm motility and mitochondrial activity. This means that the less viable the sperm cell is, the lower the ability of the spermatozoa to bind to the perivitelline membrane. Thus, the sperm binding test can be considered a method to analyze overall semen quality in dogs. As a functional test, it can evaluate simultaneously the integrity of sperm membrane, mitochondrial activity, and sperm motility.

\section{Conclusion}

The sperm-binding test to the perivitelline membrane of chicken egg yolk can be considered a feasible sperm analysis for both fertilizing capacity and overall spermattribute evaluation. In particular to the canine species it is reliable when the analysis is performed by a conventional microscope, which expands its practicality to the majority of canine reproduction laboratories.

\section{Acknowledgements}

This research was financially supported by FAPESP 2013/04494-8 and 2009/52760-3.

\section{References}

AITKEN, R. J. Sperm function tests and fertility. International Journal of Andrology, v. 29, n. 1, p. 69-75, 2006. doi: 10.1111/j.1365-2605.2005.00630.x.

AMANN, R. P.; SHABANOWITZ, R. B.; HUSZAR, G.; BRODER, S. J. In vitro sperm-binding assay to distinguish differences in populations of human sperm or damage 
to sperm resulting from cryopreservation. Journal of Andrology, v. 20, n. 5, p. 648-654, 1999. doi: 10.1002/ j.1939-4640.1999.tb02567.x.

BARBATO, G. F.; CRAMER, P. G.; HAMMERSTEDT, R. H. A practical in vitro sperm-egg binding assay that detects subfertile males. Biology of Reproduction, v. 58, n. 3, p. 686-699, 1998.

BAUSEK, N.; WACLAWEK, M.; SCHNEIDER, W. J.; WOHLRAB, F. The major chicken egg envelope protein $\mathrm{ZP1}$ is different from $\mathrm{ZPB}$ and is synthesized in the liver. The Journal of Biological Chemistry, v. 275, n. 37, p. 28866-28872, 2000. doi: 10.1074/jbc.M004944200.

BOERSMA, A.; RA $\beta$ HOFER, R.; STOLLA, R. Influence of sample preparation, staining procedure and analysis conditions on bull sperm head morphometry using the morphology analyser integrated visual optical system. Reproduction in Domestic Animals, v. 36, n. 5, p. 222-229, 2001. doi: 10.1046/j.1439-0531.2001.00291.x.

CORCINI, C. D.; SILVA, B. E.; BRIZOLARA, R. M. R.; GHELLER, S. M. M.; VARELA JUNIOR, A. S.; BONGALHARDO, D. C.; LUCIA JUNIOR, T. Concentração de lactato de cálcio e tempo de incubação sobre a capacidade de adesão e penetração de espermatozoides suínos na membrana perivitelina do ovo da galinha. Ciência Rural, v. 42, n. 1, p. 142-146, 2012. doi: 10.1590/S0103-84782012000100023.

CRISCUOLO, T. S.; ROCHA, A. M.; SEMACO, E.; SERZEDELO, T.; ALEGRETTI, J. R.; SERAFINI, P.; MOTTA, E. L. A. Motile sperm binding to egg yolk membrane is an easy and feasible function test for acrosome integrity. Jornal Brasileiro de Reprodução Assistida, v. 14, n. 4, p. 29-31, 2010.

DAHLBOM, M.; ANDERSSON, M.; VIERULA, M.; ALANKO, M. Morphometry of normal and teratozoospermic canine sperm heads using and image analyzer: work in progress. Theriogenology: an International Journal of Animal Reproduction, v. 48, n. 4, p. 687-698, 1997. doi: 10.1016/S0093-691X(97)00284-7.

FARSTAD, W. Current state in biotechnology in canine and feline reproduction. Animal Reproduction
Science, v. 60-61, p. 375-387, 2000. doi: 10.1016/S03784320(00)00106-8.

FRANKEN, D. R.; OEHNINGER, S. Semen analysis and sperm function testing. Asian Journal of Andrology, v. 14, n. 1, p. 6-13, 2012. doi: 10.1038/aja.2011.58.

HERMANSSON, U.; PONGLOWHAPAN, S.; FORSBERG, C. L.; HOLST, B. S. A short sperm-oocyte incubation time ZBA in the dog. Theriogenology: an International Journal of Animal Reproduction, v. 66, n. 4, p. 717-725, 2006. doi: 10.1016/j.theriogenology.2006.01.043.

HRUDKA, F. Cytochemical and ultracytochemical demonstration of cytochrome $\mathrm{c}$ oxidase in spermatozoa and dynamics of its changes accompanying ageing or induced by stress. International Journal of Andrology, v. 10, n. 6, p. 809-828, 1987. doi: 10.1111/j.1365-2605.1987. tb00385.x.

LAGERGREN, C. G. On the eosin-nigrosine stain and some other methods for the appraisal of sperm vitality with special reference to practical application. Annali di Ostetricia e Ginecologia, v. 75, n. 6, p. 998-1005, 1953.

LASLEY, B. L.; LOSKUTOFF, N. M.; ANDERSON, G. B. The limitation of conventional breeding programs and the need and promise of assisted reproduction in nondomestic species. Theriogenology: an International Journal of Animal Reproduction, v. 41, n. 1, p. 119-132, 1994. doi: 10.1016/S0093-691X(05)80057-3.

LOSANO, J. D. A.; ANGRIMANI, D. S. R.; PEREIRA, R. J. G.; ROCHA, A. M.; CRISCUOLO, T. S.; BARNABE, V. H.; BARNABE, R. C.; MENDES, C. M.; ASSUMPÇÃO, M. E. O. A.; NICHI, M. Utilization of sperm-binding assay combined with computer-assisted sperm analysis to evaluate frozen-thawed bull semen. Andrologia: First International Journal of Andrology, v. 47, n. 1, p. 77-84, 2015. doi: 10.1111/and.12225.

LUCIO, C. F.; REGAZZI, F. M.; SILVA, L. C.; ANGRIMANI, D. S. R.; NICHI, M.; VANNUCCHI, C. I. Oxidative stress at different stages of two-steps semen cryopreservation procedures in dogs. Theriogenology: an International Journal of Animal Reproduction, v. 85, n. 9, p. 1568-1575, 2016. doi: 10.1016/j.theriogenology.2016.01.016. 
PEÑA, A. I.; BARRIO, M.; BECERRA, J. J.; QUINTELA, L. A.; HERRADÓN, P. G. Motile sperm subpopulation in frozen-thawed dog semen: changes after incubation in capacitating and relationship with sperm survival after osmotic stress. Animal Reproduction Science, v. 133, n. $3-4$, p. 214-223, 2012. doi: 10.1016/j. anireprosci.2012.06.016.

POPE, C. E.; ZHANG, Y. Z.; DRESSER, B. L. A simple staining method for evaluating acrosomal status of cat spermatozoa. Journal of Zoo and Wildlife Medicine, v. 22, n. 1, p. 87-95, 1991.

ROBERTSON, L.; BROWN, H. L.; STAINES, H. J.; WISHART, G. J. Characterization and application of an avian in vitro spermatozoa-egg interaction assay using the inner perivitelline layer from laid chicken eggs. Journal of Reproduction and Fertility, v. 110, n. 2, p. 205-211, 1997. doi: 10.1530/jrf.0.1100205.
THOMASSEN, R.; FARSTAD, W. Artificial insemination in canids: a useful tool in breeding and conservation. Theriogenology: an International Journal of Animal Reproduction, v. 71, n. 1, p. 190-199, 2009. doi: 10.1016/j. theriogenology.2008.09.007.

VERSTEGEN, J.; IGUER-OUADA, M.; ONCLIN, K. Computer assisted semen analyzers in andrology research and veterinary practice. Theriogenology: an International Journal of Animal Reproduction, v. 57, n. 1, p. 149-179, 2002. doi: 10.1016/S0093-691X(01)00664-1.

WACLAWEK, M.; FOISNER, R.; NIMPF, J.; SCHNEIDER, W. J. The chicken homologue of zona pellucida protein-3 is synthesized by granulosa cells. Biology Reproduction, v. 59, n. 5, p. 1230-1239, 1998.

YANAGIMACHI, R. Fertility of mammalian spermatozoa: its development and relativity. Zygote, v. 2, n. 4, p. 371-372, 1994. 